\title{
Pethik Laut: Wujud Solidaritas Sosial Masyarakat Madura di Dusun Watu Ulo Kecamatan Ambulu
}

\section{Pethik Laut: The Form of Social Solidarity of Madura Society in Dusun Watu Ulo Ambulu District}

\author{
Adhitiya Prasta Pratama1), Naimatul Chariro') \& Syaiful Akbar ${ }^{2) *}$ \\ 1) Departemen Sosiologi, Fakultas Ilmu Sosial dan Hukum, Universitas Negeri Surabaya, \\ Indonesia \\ 2) Departemen Bahasa Inggris, Fakultas Ilmu Budaya, Universitas Jember, Indonesia
}

Diterima: 02 Juni 2021 Direview: 02 Juni 2021; Disetujui: 08 Agustus 2021

*Coresponding Email: adhitiyaprasta@mhs.unesa.ac.id

\begin{abstract}
Abstrak
Artikel atau tulisan ini bertujuan untuk mengungkap wujud solidaritas masyarakat Madura di Dusun Watu Ulo dalam tradisi/upacara Pethik Laut. Peneliti mengambil lokasi tersebut sebagai titik penelitian karena berdasarkan penelitian sebelumnya, literatur mengenai solidaritas sosial pada tradisi masyarakat tradisional masih terbatas. Selain itu, peneliti juga mengkaji Pethik Laut di Dusun Watu Ulo, Ambulu, Jember karena sejauh ini penelitian Pethik Laut di Jember masih sedikit. Masalah difokuskan pada wujud solidaritas sosial masyarakat Madura Dusun Watu Ulo Ketika melaksanakan tradisi tersebut. Guna mendekati masalah ini dipergunakan acuan teori dari Emile Durkheim mengenai konsep solidaritas sosial. Data-data dikumpulkan melalui sintesis wawancara daring dan studi kepustakaan, serta dianalisis secara kualitatif. Kajian ini menyimpulkan bahwa keterikatan terhadap nilai dan realitas sosial juga membentuk solidaritas. Misalnya, terdapat wujud solidaritas sosial masyarakat Madura dalam tradisi tersebut, yakni solidaritas dalam menentukan dan mempersiapkan upacara, seperti penarikan dana, pembuatan makanan, dan pengelolaan kegiatan. Sehingga, solidaritas sosial masyarakat Madura termasuk dalam jenis solidaritas mekanik Durkheim.
\end{abstract}

Kata Kunci: Wujud; Solidaritas Sosial; Pethik Laut; Madura; Watu Ulo.

\begin{abstract}
This article or writing aims to reveal the form of solidarity of the Madurese community in Watu Ulo Hamlet in the Pethik Laut tradition/ceremony. Researchers took this location as a research point because based on previous research, the literature on social solidarity in traditional community traditions is still limited. In addition, the researchers also studied the Pethik Laut in Watu Ulo Hamlet, Ambulu, Jember because so far the research on the Pethik Laut in Jember is still small. The problem is focused on the form of social solidarity of the Madurese community in Watu Ulo when carrying out this tradition. To approach this problem, Emile Durkheim's theoretical reference on the concept of social solidarity is used. The data were collected through the synthesis of online interviews and literature study, and analyzed qualitatively. This study concludes that attachment to values and social reality also forms solidarity. For example, there is a form of social solidarity among the Madurese in this tradition, namely solidarity in determining and preparing ceremonies, such as withdrawing funds, making food, and managing activities. Thus, the social solidarity of the Madurese community is included in the Durkheim type of mechanical solidarity.
\end{abstract}

Keywords: Form; Social Solidarity; Pethik Laut; Madura; Watu Ulo.

How to Cite: Pratama, A.P., Chariro, N., \& Akbar, S., (2021). Pethik Laut: Wujud Solidaritas Sosial Masyarakat Madura di Dusun Watu Ulo Kecamatan Ambulu. Journal of Education, Humaniora and Social Sciences (JEHSS). 4(2): 836-843. 


\section{PENDAHULUAN}

Konsep utama solidaritas sosial pertama kali dicetuskan oleh Emile Durkheim (18581917) dalam tesisnya "The Division of Labour in Society" (1893). Menurutnya, solidaritas sosial memiliki pengertian bahwa masyarakat dapat terintegrasi dengan cara mencapai equilibrium. Misalnya, dalam masyarakat tradisional keseimbangan homogenitas antaranggota menjadi kunci integritas, sedangkan perbedaan sosial mengintegrasi masyarakat modern (Scott, 2006). Selain itu, munculnya pengintegrasian antaranggota masyarakat juga berdasarkan pada kelompok sosial, yakni paguyuban dan patembayan (Tonnies \& Harris, 2001).

Namun, menurut Marx (1818-1883) equilibrium bukanlah hal yang mampu mengintegrasi, tetapi konflik kelas-lah akar dari solidaritas. Bagi Marx, wilayah yang mencakup kondisi, kepentingan, nasib, dan musuh yang sama mendasari anggota kelas untuk berintegrasi (Scott, 2006). Sehingga dalam kata lain, hubungan sosial berperan besar sebagai konstruksi solidaritas. Akan tetapi, Weber (1864-1920) melihat bahwa solidaritas yang terbentuk dari kesamaan rasa dan nasib oleh Marx masih bersifat idealis. Pasalnya, banyak terjadi perpecahan antara pekerja di sepanjang garis lokalitas, industri, jenis kelamin, usia, agama, etnis, dan kebangsaan (Scott, 2006). Oleh karena itu, dalam pandangan Weber konflik tidak memunculkan suatu solidaritas, melainkan mempromosikan persaingan antar kelompok.

Georg Simmel (1858-11918) mengamati lebih lanjut mengenai kuat tidaknya solidaritas sosial yang terjadi dalam masyarakat. Ia berpendapat bahwa kuatnya hubungan anggota masyarakat karena adanya relasi rahasia yang eksklusif, seperti mafia dan perkumpulan khusus (Scott, 2006). Maka dari itu, Simmel menegaskan bahwa rasa ketergantungan dan nasib kolektif yang tinggi menjadi landasan solidaritas sosial. Sehingga, dapat disimpulkan bahwa inti pemikiran klasik mengenai makna solidaritas sosial menurut Smelser (1962) adalah perilaku kolektif yang mencakup kepercayaan fundamental dalam menghadapi perubahan, pertentangan, maupun dominasi struktur.

Oleh karena itu, penulisan ini berfokus pada tesis utama konsep solidaritas sosial yang digagas oleh Durkheim. Penggunaan konsep tersebut bertujuan untuk menanggapi fenomena sosial yang terjadi dalam kehidupan masyarakat. Sebelumnya, Durkheim berpendapat bahwa fakta sosial juga turut melahirkan solidaritas, ia menyatakan bahwa terdapat kekuatan yang memaksa individu untuk bersatu, seperti hukum dan budaya (Kurniawan, 2020). Kemudian, Durkheim membagi solidaritas sosial ke dalam dua bagian, yakni solidaritas mekanik dan solidaritas organik. Solidaritas mekanik berlandaskan atas persamaan atau homogenitas individu. Sehingga, dalam penerapannya terdapat kesadaran kolektif (collective conscience) yang mendukung masyarakat menjadi satu dan seragam. Sedangkan, solidaritas organik merupakan bentuk solidaritas yang terjadi pada masyarakat beragam atau heterogen. Durkheim menyatakan (dalam Kurniawan, 2020) bahwa sebenarnya masyarakat saling membutuhkan satu sama lain. Sehingga, keberagaman bukan hal pemicu kerusakan, melainkan hubungan terikat yang bersifat mutualisme.

Selanjutnya, Durkheim menjelaskan bahwa solidaritas organik biasa dijumpai di daerah modern, khususnya perkotaan. Karena, di daerah tersebut memiliki individu yang beragam, dan masing-masing anggota masyarakat modern hanya mampu melakukan sederet tugas yang relatif sempit, sehingga mereka harus berintegrasi dengan anggota masyarakat lain untuk bertahan hidup (Ritzer, 2012). Sedangkan, solidaritas mekanik banyak dijumpai pada masyarakat perdesaan atau tradisional. Ia berargumen (dalam Ritzer, 2012) bahwa masyarakat tradisional memiliki nurani kolektif yang kuat, yakni terhadap pengertian norma dan kepercayaankepercayaan yang dianut bersama. Dengan demikian, peneliti berasumsi bahwa gagasan yang diutarakan Durkheim lebih relevan untuk mengkaji solidaritas sosial masyarakat Madura dalam tradisi Pethik Laut di Dusun Watu Ulo, Kecamatan Ambulu, Jember.

Secara kultural, tradisi Pethik Laut masyarakat Madura Dusun Watu Ulo merupakan upacara turun-temurun sebagai wujud rasa syukur kepada Tuhan (Agustin, 17 Desember 2020). Dalam kaitannya, tradisi tersebut merupakan sebuah masa di mana para nelayan dan alam (laut) memiliki hubungan yang saling berkesinambungan. Oleh karena itu, untuk menghargai dan 
mensyukuri berkah Tuhan melalui alam, para nelayan memberikan suatu upacara/selamatan, yakni dengan Pethik Laut. Selain itu, tradisi Pethik Laut juga merepresentasikan upaya masyarakat untuk saling bergotong royong. Pasalnya, tradisi tersebut tidak akan berjalan jika tidak ada koordinasi dan solidaritas ataranggota masyarakat.

Dengan demikian, sebagai bahan referensi literatur untuk menempatkan posisi peneliti dalam penulisan, peneliti mengumpulkan beberapa penelitian terdahulu yang terkait dan sejenis. Misalnya, penelitian Solidaritas Sosial Berbasis Nilai Tradisi Lokal oleh Funay (2020). Selanjutnya, penelitian oleh Nopianti (2016) terhadap wujud solidaritas sosial masyarakat Kasepuhan Sinaresmi dalam tradisi Leuit Si Jimat. Kemudian, Kumalasari (2017) dengan penelitiannya mengenai makna solidaritas sosial dalam tradisi Sedekah Desa di Desa Ngogri, Jombang. Setelah itu, penelitian kearifan lokal sebagai upaya membangun solidaritas dan integritas sosial masyarakat Desa Bukit Batu, Bengkalis oleh Hasbullah (2012). Dalam temuan masing-masing peneliti tersebut, pada intinya solidaritas sosial berupaya untuk menekan kecenderungan individualitas anggota masyarakat. Selain itu, kebersamaan dan keterikatan anggota masyarakat berkontribusi dalam konstruksi solidaritas sosial. Sehingga, dengan adanya rasa kebersamaan antaranggota masyarakat mampu mengangkat nilai-nilai tradisi dan mengurangi ketegangan di tengah masyarakat.

Selain literatur yang berkaitan dengan solidaritas sosial, penulisan ini juga mengumpulkan beberapa penelitian mengenai tradisi Pethik Laut. Berdasarkan penelusuran daring, peneliti menemukan beberapa penelitian Pethik Laut yang berlokasi di Muncar, Banyuwangi, Jawa Timur. Misalnya, penelitian oleh Ainiyah (2017a) dan (2017b) yang meneliti keragaman dan komunikasi ritual Pethik Laut terhadap nelayan di Kedungrejo. Setelah itu, ia meneliti akomodasi sosialideologis komunitas nelayan di lokasi yang sama. Selanjutnya, Wulandari (2013) meneliti mitos dalam upacara Pethik Laut masyarakat Madura yang ada di Muncar, Banyuwangi. Namun, penelitian mengenai Pethik Laut sepenuhnya tidak hanya berlokasi di Kabupaten Banyuwangi, melainkan terdapat di Kabupaten Jember, yakni di Kecamatan Kencong. Sebagai contoh, penelitian oleh Wibowo (2015) yang mengkaji tradisi sedekah Pethik Laut di Desa Paseban, Kencong.

Oleh sebab itu, dalam penulisan ini berasumsi bahwa penelitian mengenai solidaritas sosial masih terbatas, terutama dalam masyarakat tradisional. Selain itu, penulisan ini juga mengambil lokasi yang berbeda dengan penelitian Pethik Laut sebelumnya, yakni di Dusun Watu Ulo, Desa Sumberejo, Kecamatan Ambulu, Kabupaten Jember. Maka dari itu, penulisan ini mencoba mengkaji solidaritas masyarakat Madura dalam tradisi Pethik Laut di daerah tersebut. Sehingga, penulisan ini dapat menjawab fenomena, "Apakah dalam tradisi Pethik Laut di Dusun Watu Ulo, Kecamatan Ambulu terdapat wujud solidaritas sosial pada masyarakat Madura?".

\section{METODE PENELITIAN}

Menurut Sugiyono (2013) metode penelitian pada dasarnya merupakan cara ilmiah untuk mendapatkan data dengan tujuan dan kegunaan tertentu. Cara ilmiah bertujuan mendasari kegiatan penelitian yang mencirikan keilmuan. Ciri-ciri keilmuan tersebut meliputi rasional, empiris, dan sistematis. Rasional memiliki sifat yang dapat dijangkau oleh nalar manusia dan menekankan pada cara-cara masuk akal sedangkan empiris berarti dapat ditangkap dan dilakukan secara inderawi dan sistematis merupakan proses yang digunakan dalam penelitian yang berdasarkan langkah-langkah berurutan dan logis.

Penulisan ini menggunakan pendekatan kualitatif. Pendekatan kualitatif merupakan metode penelitian yang berlandaskan pada filsafat postpositivisme (Sugiyono, 2013). Kirk dan Miller (1986) mengartikan penelitian kualitatif sebagai tradisi ilmu sosial yang secara fundamental bergantung pada pengamatan manusia, baik dalam kawasannya maupun istilahnya (Berlian, 2016). Tujuan penulisan menggunakan metode kualitatif deskriptif karena solidaritas sosial masyarakat Madura di Dusun Watu Ulo tidak dapat diuji dengan kuantitas. Sehingga, penulisan ini memilih metode tersebut untuk mempermudah interpretasi data. Di samping itu, metode ini berupaya menggambarkan realitas dengan mengembangkan beberapa perspektif, salah satunya adalah dengan melakukan wawancara daring pada masyarakat setempat yang terlibat langsung 
dalam Pethik Laut. Sehingga, penulisan ini akan menemukan fakta-fakta dari fenomena realitas sosialnya.

Wawancara daring menjadi opsi paling mudah karena situasi Covid-19 saat ini masih belum kondusif. Teknik tersebut pada dasarnya sama seperti teknik wawancara sebelumnya, yakni komunikasi dua arah antara pewawancara dan narasumber. Hanya saja, yang menjadi perbedaan adalah media. Pada teknik wawancara daring dibutuhkan media tambahan berupa telepon seluler dan aplikasi pendukung seperti Whatsapp. Selain menggunakan wawancara daring, penulisan ini juga menggunakan metode kepustakaan. Studi pustaka menurut Zed (2014) ialah serangkaian kegiatan penelitian dengan menggunakan data pustaka. Selanjutnya, Sugiyono mengartikan penelitian pustaka sebagai kajian teoretis dan literatur ilmiah yang berhubungan dengan nilai dan norma pada situasi sosial yang diteliti (Sari \& Asmendri, 2018). Zed membagi langkah penelitian kepustakaan menjadi empat. Pertama, menyiapkan alat pencatat berupa alat tulis dan kertas catatan. Kedua, menyusun bibliografi dengan mencatat bahan sumber utama rujukan penelitian. Ketiga, mengelola waktu berdasarkan cara dan kebutuhan peneliti. Keempat, membaca sumber rujukan dan mencatat poin-poin penting sebagai bahan penelitian.

Jenis data yang diperoleh merupakan data sekunder, meliputi artikel, jurnal, dokumen, buku, media massa, internet, data statistik, dan berbagai sumber terkait lainnya sebagaimana dikemukakan Salim dan Haidir (dalam Ichsan, 2020). Penulisan ini lebih mengutamakan studi kepustakaan, sehingga studi lapangan berupa wawancara daring hanya sebagai data pendukung. Selanjutnya, data yang diperoleh kemudian diolah, dianalisis, dan disimpulkan untuk mendapat hasil penelitian.

Pada penerapan metodologinya, peneliti mengalami kesulitan dalam melakukan wawancara. Pasalnya, wawancara secara daring berbeda dengan wawancara langsung. Selain itu, keterbatasan jaringan juga menjadi penghambat jalannya wawancara. Akan tetapi, peneliti berusaha semaksimal mungkin mencari informasi melalui media daring dan semacamnya. Sehingga, dalam penulisan ini peneliti berharap data yang disuguhkan dapat memenuhi standard metodologisnya. Selain itu, terdapat beberapa alasan yang mendasari penggunaan teknik tersebut. Pertama, data pustaka masih tetap valid untuk menjawab persoalan peneliti (Zed, 2014). Kedua, terkadang peneliti hanya memperoleh sumber data melalui studi kepustakaan apabila studi lapangan kurang memadai. Ketiga, keterbatasan ruang gerak dalam situasi pandemi Covid-19, sehingga membuat peneliti membatasi kontak langsung dengan siapa pun..

HASIL DAN PEMBAHASAN

Gambaran Umum dan Sejarah Masuknya Masyarakat Madura di Dusun Watu Ulo, Ambulu

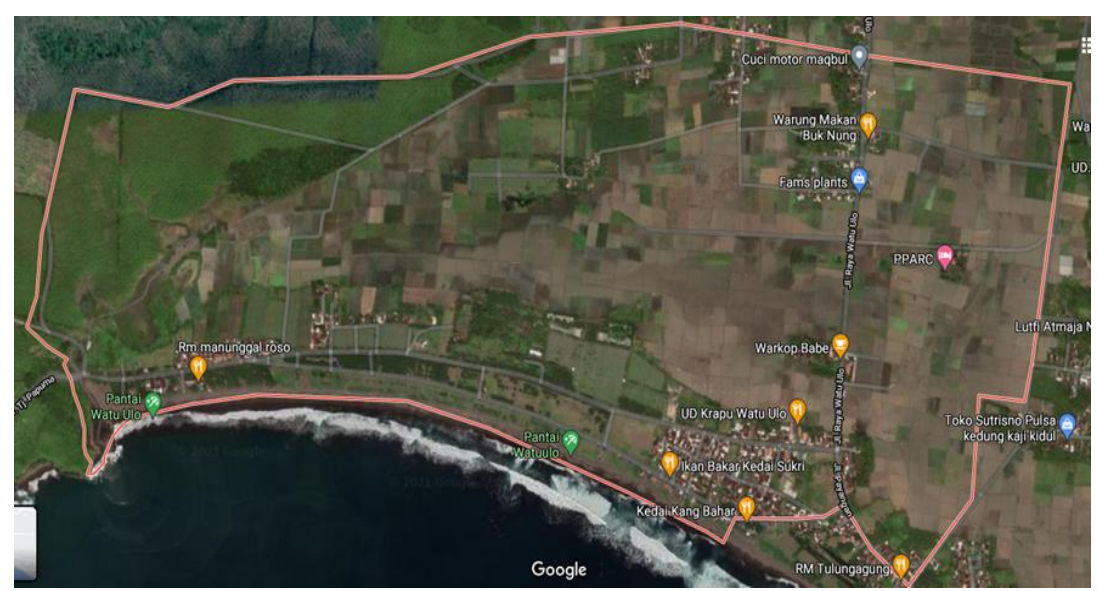

Gambar 1. Peta Dusun Watu Ulo, Ambulu, Jember. Sumber: Google Maps

Dusun Watu Ulo merupakan satu dari enam dusun yang terdapat di Desa Sumberejo, Kecamatan Ambulu. Sebagai bagian dari kota wisata, Dusun Watu Ulo memiliki keunikan tersendiri selain beberapa pantai yang indah, yakni terdapat komunitas etnik Madura. Meskipun 
komunitas tersebut tidak juga disebut sebagai komunitas adat, tetapi dalam aktivitasnya masih memegang teguh budaya dan tradisi warisan leluhurnya. Hal tersebut sejalan dengan pengertian Rosyadi (dalam Nopianti, 2016) bahwa komunitas adat merupakan sekelompok orang yang hidup di suatu wilayah tertentu dengan tetap mempertahankan tradisi leluhur dalam kehidupan seharihari. Akan tetapi, dalam beberapa penelusuran daring, sejarah masuknya komunitas etnik Madura ke Ambulu belum banyak memiliki literatur. Namun, eksistensi komunitas etnik Madura di Ambulu, khususnya di Dusun Watu Ulo tidak terlepas dari kebudayaan Pandhalungan di Jember.

Istilah Pandhalungan merujuk pada hibridisasi antara suku Jawa dan suku Madura yang hidup di wilayah Tapal Kuda, Jawa Timur (Zoebazary, 2017). Wilayah Tapal Kuda merupakan suatu kawasan di Jawa Timur yang menyerupai ladam atau sepatu kuda (Sutarto, 2006). Kota-kota yang berada di wilayah tersebut meliputi Lumajang, Bondowoso, Situbondo, Probolinggo, Jember, serta sebagian dari Banyuwangi dan Pasuruan.

Secara historis, munculnya kebudayaan Pandhalungan salah satunya adalah emigrasi orangorang Madura ke Jember. Persebaran masyarakat Madura ke Jember tercatat sejak Kerajaan Majapahit, yakni pada abad ke-13 sampai abad ke-18. Selain itu, politik transmigrasi yang dilakukan pemerintah kolonial Belanda memaksa penduduk asli daerah tertentu untuk menjadi pekerja di lahan-lahan baru milik Belanda. Sehingga, pada abad ke-19 emigrasi penduduk Madura mengalami peningkatan yang signifikan. Oleh karenanya, komposisi penduduk Madura dan Jawa tidak seimbang, penduduk Madura lebih banyak dibandingkan penduduk Jawa (Gennep, 1909). Tujuan lain dari emigrasi etnik Madura pada masa itu karena etnik Madura datang untuk mencari penghidupan yang lebih baik, di samping itu juga tekanan letak geografis pulau Madura yang kurang memadai (Ayu, 2018).

Dengan demikian, hingga saat ini persebaran komunitas etnik Madura masih dapat dijumpai di Kabupaten Jember, khususnya di Jember bagian utara, seperti di Kecamatan Arjasa, Jelbug, Sukowono, Kalisat, Sumberjambe, Ledokombo, Mayang, dan sebagian Pakusari. Namun, eksistensi komunitas penduduk Madura di Jember juga terdapat di Jember bagian selatan, misalnya di Kecamatan Jenggawah, Tempurejo, Kencong, Puger, dan tak terkecuali Ambulu.

Berdasarkan cerita dari warga Ambulu, penamaan kata Ambulu ternyata juga memiliki historis yang berkaitan dengan etnik Madura. Kata Ambulu berasal dari para pekerja Madura yang ditugaskan oleh pemerintah kolonial Belanda untuk membuka lahan di daerah tersebut. Karena kelelahan, para pekerja tersebut berkata kepada pekerja lain untuk beristirahat terlebih dahulu. Mereka berkata dengan bahasa Madura dengan kalimat, "Ambu Gelu!" yang mana Ambu berarti berhenti/istirahat dan Gelu berarti sejenak. Sehingga, secara definitif dapat diartikan bahwa Ambu Gelu dimaksudkan oleh para pekerja Madura sebagai ajakan untuk beristirahat sejenak. Istilah tersebut seiring dengan berjalannya waktu berubah dari frasa Ambu Gelu menjadi Ambulu hingga saat ini.

Komunitas etnik Madura yang tinggal di Dusun Watu Ulo memiliki profesi yang beragam, namun mayoritas berprofesi sebagai nelayan dan perikanan. Selain itu, mereka juga berprofesi sebagai pedagang, penjual cenderamata, dan aneka jajanan khas. Hal tersebut karena Dusun Watu Ulo merupakan bagian dari kota wisata yang permukimannya berbatasan langsung dengan laut. Oleh karena itu, untuk menggaet wisatawan lokal maupun asing masyarakat setempat setiap tahunnya melakukan beberapa tradisi, sebagaimana tradisi Pethik Laut.

\section{Ritus Sosial dan Tradisi Pethik Laut di Dusun Watu Ulo}

Ritual merupakan sebuah cara yang dipahami sebagai komunikasi simbolik berdasarkan konstruksi kultural, seperti upacara, tradisi, liturgi, dan kepercayaan magis (Grimes, 1983). Sejalan dengan itu, Schilderman dkk., (2007) menjelaskan bahwa ritual adalah kerangka kerja tindakan interpretatif. Sehingga, kerangka tersebut dapat dipelajari dalam berbagai macam bentuk empiris, yakni dengan memperhatikan kondisi, fungsi, dan tujuannya. Dengan demikian, dapat disimpulkan bahwa ritus sosial hadir berdasarkan realitas sosial masyarakat.

Pada penerapannya, ritus dan agama adalah dua konsepsi yang tidak dapat dipisahkan. Konsepsi agama menurut Durkheim (dalam Haryanto, 2015) meliputi dua perbedaan kategori yang saling berlawanan, yakni antara yang sakral dan profan serta kolektif dan individual. Sakral 840त्वि http://mahesainstitute.web.id/ojs2/index.php/jehss

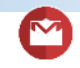


merujuk pada sesuatu yang bersifat suci, ketuhanan, dan transendental. Sementara profan lebih bersifat duniawi, tidak suci, dan dapat dikendalikan manusia. Selain itu, agama/kepercayaan memiliki penerapan secara kolektif, seperti ritual yang dilakukan orang banyak. Sedangkan, praktik individual lebih berorientasi pada sesuatu magis.

Dengan demikian, kepercayaan yang dimiliki komunitas etnik Madura di Dusun Watu Ulo cenderung mengarah ke ritual kolektif yang tercermin pada tradisi Pethik Laut. Ritual kolektif bertujuan untuk mencapai segala sesuatu bersama-sama. Pada tradisi Pethik Laut di Dusun Watu Ulo, tujuan yang ingin dicapai masyarakat adalah keberkahan. Selain itu, tradisi tersebut sebagai ungkapan rasa syukur masyarakat. Biasanya, tradisi Pethik Laut dilaksanakan pada bulan Muharam (Syuro). Acara tersebut dihadiri oleh berbagai lapisan masyarakat setempat, yang kemudian saling bergotong royong mempersiapkan upacara.

Berdasarkan sumber dari laman Warisan Budaya Takbenda oleh Kemendikbud, pelaksanaan tradisi Pethik Laut oleh masyarakat Dusun Watu Ulo diselenggarakan di bulan Syuro pada tanggal 10. Upacara tersebut dimulai dengan acara kenduri/selamatan satu hari sebelum pelarungan sesaji dilaksanakan. Selanjutnya, terdapat pembacaan pakem oleh tetua desa semalam suntuk. Setelah itu, keesokan harinya upacara Pethik Laut diawali dengan kesenian-kesenian lainnya, seperti pertunjukan wayang, tari-tarian, dan pertunjukan musikal drum band. Kemudian, acara pelarungan sesaji pun dilaksanakan. Para sesepuh desa sebelum membawa sesajen tersebut ke laut lepas, terlebih dahulu dibawa ke Balai Desa untuk didoakan. Selanjutnya, diiringi warga yang bahu-memabahu menjaga kestabilan kapal membawa sesajen ke laut lepas. Sesajen tersebut berisikan kepala kambing, ayam jantan, buah-buahan, dan lain sebagainya.

Namun, terdapat pula sesajen lainnya, misalnya seperti tumpeng dan makanan konsumsi. Hal tersebut bertujuan agar para warga juga dapat menikmati makanan yang telah disiapkan. Terakhir, setelah acara pelarungan upacara ditutup dengan kesenian wayang kulit semalam suntuk atau pertunjukan musik. Lalu, tokoh desa akan berdoa bersama warga setempat sebagai simbol penutup upacara tersebut.

\section{Analisis Data Tentang Wujud Solidaritas Sosial dalam Tradisi Pethik Laut}

Menurut Durkheim (dalam Johnson, 2008) menyatakan bahwa ritual keagamaan yang dilakukan bersama-sama dapat memperkuat kesadaran kolektif (hati nurani). Ritual/upacara melahirkan rasa emosional bersama, sehingga mampu membentuk solidaritas sosial sebagai penguat kepercayaan agama dan kode moral.

Salah satu landasan terbentuknya wujud solidaritas sosial adalah budaya gotong-royong. Keterikatan serta persamaan nilai yang sama menciptakan anggota masyarakat saling bergantung dan tolong-menolong. Budaya gotong-royong tersebut dapat dilihat pada tradisi Pethik Laut di Dusun Watu Ulo. Sebelum itu, Koentjaraningrat membagi gotong royong ke dalam dua jenis, yaitu gotong royong dalam bentuk kerja bakti dan tolong-menolong (Colleta, 1987). Gotong royong dalam bentuk kerja bakti merupakan gotong-royong yang berorientasi kepada kepentingan umum, baik dari kesadaran maupun dari peraturan penjadwalan. Sedangkan, gotong royong dalam bentuk tolong menolong merupakan gotong royong yang banyak terjadi pada aktivitas upacara, pesta, dan perayaan. Dengan demikian, gotong-royong yang terjadi dalam upacara/tradisi Pethik Laut di Dusun Watu Ulo merupakan tipe gotong-royong tolong menolong. 


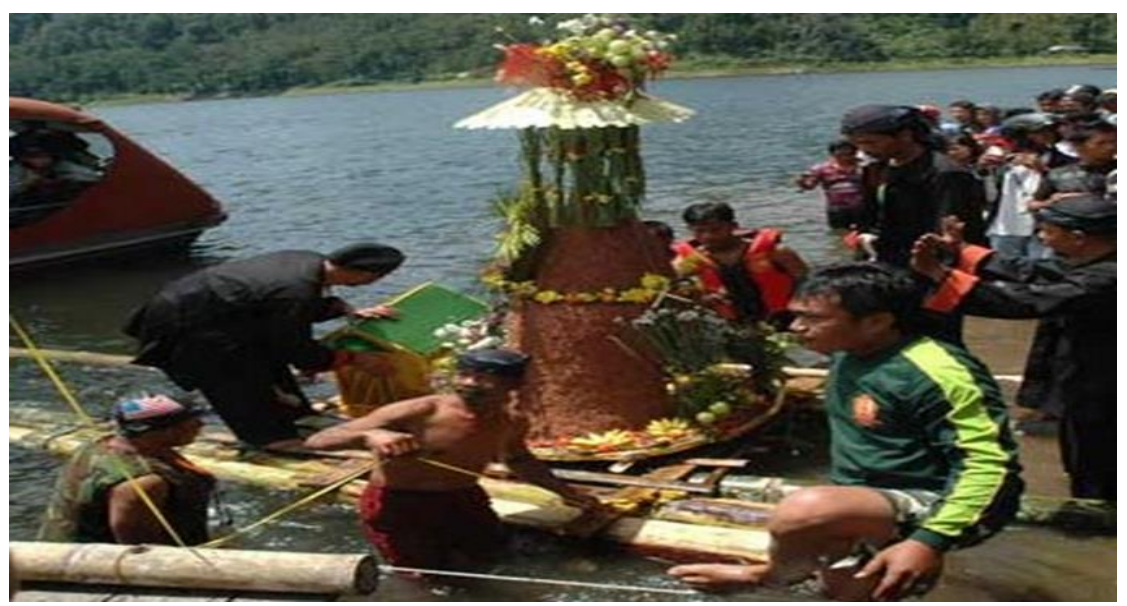

Gambar 3. Pelarungan Sesaji Oleh Warga Setempat. Sumber: visitwatuulo.blogspot

Berdasarkan analisis penulisan ini, peneliti menemukan beberapa wujud solidaritas sosial masyarakat Madura di Dusun Watu Ulo dalam tradisi Pethik Laut. Pertama, wujud solidaritas dalam Musyawarah dan Penarikan dana. Tahap tersebut dimulai dengan berkumpulnya tokohtokoh desa untuk membahas serta merencanakan pelaksanaan tradisi Pethik Laut. Kemudian, dalam musyawarah tersebut para anggota lain juga diperkenankan mengutarakan pendapat, sehingga musyawarah dapat berjalan interaktif dan saling menguntungkan. Selanjutnya, setelah keputusan sudah disetujui oleh masing-masing lapisan warga, lalu beralih ke penarikan dana. Penarikan dana tersebut biasannya bersumber dari warga-warga setempat dan tidak ada patokan khusus mengenai berapa nominal yang harus disumbangkan.

Kedua, dalam acara rewangan, acara tersebut biasanya bertujuan pada persiapan konsumsi, baik makanan untuk kenduri maupun kelengkapan upacara seperti sesaji. Para warga bahumembahu mempersiapkan kelangsungan acara tersebut, ada yang membawa perlengkapan dari rumah maupun melakukan bersama-sama anggota masyarakat lain. Ketiga, berkontribusi dalam setiap kegiatan, yakni kepanitiaan, kenduri, upacara, dan hiburan. Seluruh lapisan masyarakat secara kompak mengikuti jalannya tradisi tersebut dari pra-upacara hingga hari pelaksanaan.

\section{SIMPULAN}

Berdasarkan penjelasan di atas, tradisi Pethik Laut di Dusun Watu Ulo, Desa Sumberejo, Kecamatan Ambulu merupakan suatu sarana untuk mewujudkan solidaritas sosial masyarakat Madura. Secara sosiologis, solidaritas sosial masyarakat Madura dalam tradisi tersebut termasuk dalam solidaritas mekanik Durkheim. Hal tersebut dapat dibuktikan dengan adanya kesadaran kolektif yang kuat serta persamaan nilai dan norma antar masyarakat. Wujud solidaritas sosial masyarakat Madura tercermin ketika upacara/tradisi sedang berlangsung, seperti musyawarah, gotong-royong, dan pengelolaan kegiatan. Selain itu, kepercayaan masyarakat serta ritus juga mendasari adanya solidaritas. Dengan demikian, ritual merupakan kerangka interpretatif berdasarkan realitas sosial masyarakat setempat. Dilaksanakannya tradisi Pethik Laut adalah hasil dari homogenitas serta realitas sosial masyarakat Dusun Watu Ulo, yakni realitas yang mengungkap bahwa terdapat persamaan profesi sebagai nelayan. Dengan demikian, secara turuntemurun masyarakat Madura di Dusun Watu Ulo akan tetap melaksanakan tradisi tersebut, baik sebagai sebuah upacara maupun wujud solidaritas.

\section{DAFTAR PUSTAKA}

Berlian, E. (2016). Metodologi Penelitian Kualitatif dan Kuantitatif. In Sukabina (Pertama). Penerbit Sukabina Press.

Colleta, N. J. (1987). Kebudayaan dan Pembangunan, sebuah pendekatan Terhadap Antropologi Terapan Ilmu Pengetahuan Sosial Di Indonesia. Yayasan Obor Indonesia.

Durkheim, E., Coser, L., \& Halls, W. D. (1984). The Division of Labour in Society (W. D. Halls (ed.)). The Macmillan Press LTD.

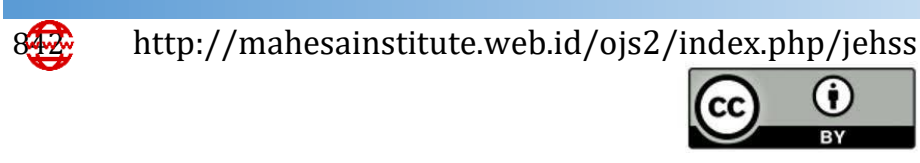

mahesainstitut@gmail.com 
Gennep, A. Van. (1909). Les Rites de Passage. University of Chicago Press.

Grimes, R. L. (1983). Beginnings in Ritual Studies. University Press of America. https://doi.org/https://doi.org/10.2307/3711511

Haryanto, S. (2015). Sosiologi Agama: Dari Klasik Hingga Postmodern (Andien (ed.); Pertama). Ar-Ruzz Media.

Ichsan, A. S. (2020). Pandemi Covid-19 dalam Telaah Kritis Sosiologi Pendidikan. Magistra: Jurnal Keguruan Dan Ilmu Pendidikan, 7(1), 1-9.

Johnson, D. P. (2008). Contemporary Sociological Theory: An Integrated Multi-Level Approach. Springer Science+Business Media, LLC.

Kurniawan, K. N. (2020). Kisah Sosiologi: Pemikiran Yang Mengubah Dunia dan Relasi Manusia (Pertama). Yayasan Pustaka Obor Indonesia.

Nopianti, R. (2016). Leuit Si Jimat : Wujud Solidaritas Sosial Masyarakat di Kasepuhan Sinarresmi. Patarjala, 8, 224. https://doi.org/http://dx.doi.org/10.30959/patanjala.v8i2.74

Ritzer, G. (2012). Teori Sosiologi: Dari Sosiologi Klasik Sampai Perkembangan Terakhir Postmodern (W. A. Djohar (ed.); Kedelapan). Pustaka Belajar.

Sari, M., \& Asmendri. (2018). Penelitian Kepustakaan (Library Research) dalam Penelitian Pendidikan IPA. Penelitian Kepustakaan (Library Research) Dalam Penelitian Pendidikan IPA, 2(1), 15. https://ejournal.uinib.ac.id/jurnal/index.php/naturalscience/article/view/1555/1159

Schilderman, H. (2007). Discourse in Ritual Studies (H. Schilderman (ed.)). Koninklijke Brill NV.

Scott, J. (2006). Sociology: The Key Concept (Routledge Key Guides). Taylor \& Francis e-Library.

Smelser, N. J. (1962). Theory of Collective Behavior. The Free Press.

Sugiyono. (2013). Metode Penelitian Kuantitatif, Kualitatif Dan R\&D (Kesembilan belas). CV. Alfabeta.

Sutarto, A. (2006). Sekilas Tentang Masyarakat Pandalungan.

Tonnies, F., \& Harris, J. (2001). Community and Civil Society (J. Harris \& M. Hollis (eds.)). Cambridge University Press.

W, A. A. (2018). Nama Diri Pendalungan Jember dalam Kebermaknaan Sosial Budaya. Jantra, 25-42.

Zed, M. (2014). Metode Penelitian Kepustakaan (Ketiga). Yayasan Pustaka Obor Indonesia.

Zoebarazy, M. I. (2017). Orang Pendalungan: Penganyam Kebudayaan di Tapal Kuda. Paguyupan Pandhalungan Jember Pancakarya, Ajung, Jember. 